\title{
Methods of inducing conditioned food aversion to Baccharis coridifolia (mio-mio) in cattle
}

\author{
Métodos de indução de aversão alimentar condicionada a \\ Baccharis coridifolia (mio-mio) em bovinos
}

\section{Milton Begeres de Almeida ${ }^{\mathrm{I}}$ Ana Lucia Schild ${ }^{\mathrm{II}}$ James Pfister ${ }^{\mathrm{III}}$ Marcelo Pimentel $^{\mathrm{IV}}$ Karine Maciel Forster ${ }^{\mathrm{IV}}$ Franklin Riet-Correa $^{\mathrm{V}}$}

\begin{abstract}
Three experiments were performed to determine the efficacy of various methods of averting naïve cattle to prevent Baccharis coridifolia poisoning: forced oral administration of $0.5 \mathrm{~g} \mathrm{~kg}^{-1}$ body weight of fresh $\boldsymbol{B}$. coridifolia; forced inhalation of the smoke from burning $\boldsymbol{B}$. coridifolia and rubbing the plant on the animals'muzzles and mouths; and introducing the animals into paddocks with low invasion by $\boldsymbol{B}$. coridifolia. Results demonstrated that cattle forced to ingest low doses become strongly averted if introduced into paddocks 23-26 hours after the aversion. In contrast, cattle introduced into the paddocks between 1-10 hours were not fully averted. Inhalation of $\boldsymbol{B}$. coridifolia smoke, and rubbing the plant on the animals' muzzles and mouths were not efficient to induce an aversion. The introduction of cattle into paddocks with approximately $1 \%$ of $\boldsymbol{B}$. coridifolia was efficient if the animals remained 5 months in the area, but not if they only remained for 60 hours, as cattle required sufficient time to learn to avoid the plant.
\end{abstract}

Key words: Baccharis coridifolia, cattle, food-conditioned aversion, plant poisoning control.

\section{RESUMO}

Foram realizados três experimentos para determinar a eficácia de vários métodos de aversão a Baccharis coridifolia em bovinos: administração oral forçada de $0,5 \mathrm{~g} \mathrm{~kg}^{-1}$ de peso vivo de B. coridifolia fresca; inalação forçada da fumaça proveniente da queima de $\boldsymbol{B}$. coridifolia e esfregação da planta no focinho e na boca dos animais; e introdução dos animais em pastagens com baixa infestação por B. coridifolia. Os resultados demonstraram que os animais forçados a ingerir pequenas doses tornaram-se fortemente avertidos, quando introduzidos nos piquetes entre 23 a 26 horas após a aversão. Entretanto, bovinos introduzidos nos piquetes após 1 a 10 horas não foram totalmente avertidos. Inalação da fumaça de $\boldsymbol{B}$. coridifolia e esfregação da planta no focinho $e$ boca dos animais não foram eficientes para produzir aversão. A introdução de bovinos em piquetes com aproximadamente 1\% de B. coridifolia foi eficiente quando os animais permaneceram cinco meses na área, mas não quando ficaram apenas 60 horas, pois os bovinos precisam de tempo para aprender a evitar a planta.

Palavras-chave: Baccharis coridifolia, bovino, aversão alimentar condicionada, controle de intoxicação por plantas.

\section{INTRODUCTION}

Baccharis coridifolia, known as mio-mio, is a very important toxic plant affecting ruminants and horses in southern Brazil, Argentina and Uruguay (TOKARNIA et al., 2012; RIET-CORREA \& MÉNDEZ, 2007). In the Brazilian state of Rio Grande do Sul poisoning by this plant has been reported in cattle (RISSI et al., 2005), sheep (ROZZA et al., 2006) and horses (ALDA et al., 2009) causing considerable economic losses. The poisoning occurs when animals with no previous experience with this plant are introduced into regions where $\boldsymbol{B}$. coridifolia is present (BARROS, 1998; TOKARNIA et al., 2012; RIET-CORREA \& MÉNDEZ, 2007). Animals born and bred in regions where $\boldsymbol{B}$. coridifolia occurs do

IFaculdade de Medicina Veterinária, Universidade Federal do Pará (UFPA), Avenida dos Universitários s/n Jaderlândia, 68746-360, Castanhal, PA, Brasil. E-mail: begeres@yahoo.com.br.*Autor para correspondência.

"Laboratório Regional de Diagnósticos (LRD), Faculdade de Veterinária, Universidade Federal de Pelotas (UFPel), Pelotas, RS, Brasil.

IIIAgriculture Research Service (ARS), United States Departament of Agriculture (USDA), Poisonous Plant Research Laboratory, Logan, UT, EUA.

${ }^{\mathrm{IV}}$ Faculdade de Agronomia Eliseu Maciel (FAEM), UFPel, Pelotas, RS, Brasil.

vHospital Veterinário, Centro de Saúde e Tecnologia Rural (CSTR), Universidade Federal de Campina Grande (UFCG), Patos, PB, Brasil. 
not ingest the plant and rarely become intoxicated (TOKARNIA et al., 2012), with the exception of recently born animals that are beginning to graze. Animals reared in areas where the plant exists are not intoxicated because they develop a strong aversion to $\boldsymbol{B}$. coridifolia after consuming small amounts of it (ALMEIDA et al., 2009). Prevention of intoxication is based on management methods to prevent mio-mio ingestion by animals not previously exposed to this plant, especially after naïve animals are transported to infested pastures. Empirically, farmers attempt to prevent $\boldsymbol{B}$. coridifolia poisoning by burning plant material under an animals' nose, and having the animal inhale the resulting smoke, or by rubbing the plant on the animals' muzzle and mouth. These prophylactic methods have been used since the time of the colonization of South America by the Spaniards (COBO, 1653).

Another way to avoid intoxication is to first graze naive animals in an area with a low density of $\boldsymbol{B}$. coridifolia, and after a certain period, to move them to a more densely infested area, thus avoiding ingestion of toxic amounts of the plant. After a few days, the animals stop eating the plant and may be moved to a fully-invaded area (TOKARNIA \& DÖBEREINER, 1975; TOKARNIA et al., 2012).

B. coridifolia may be the only poisonous plant in Brazil that induces an aversion naturally and continuously. Experimental studies have shown that it is possible to produce an aversion in sheep by administration of $25 \%$ of the lethal dose of $\boldsymbol{B}$. coridifolia (ALMEIDA et al., 2009). The objectives of this study were determine the efficacy of empirical aversion methods used to reduce the poisoning of cattle by $\boldsymbol{B}$. coridifolia in Rio Grande do Sul, Brazil, and to establish new methods to prevent toxicity and reduce economic losses. For this, 3 methods were tested: 1) forced oral administration of $\boldsymbol{B}$. coridifolia with nearly $25 \%$ of the toxic dose $(2 \mathrm{~g} / \mathrm{kg}$ of body weight of green plant in sprouting); 2) forced inhalation of the smoke from burning $\boldsymbol{B}$. coridifolia and rubbing the plant on the animals' muzzles and mouths; and 3) introducing cattle into pastures with a low population of $\boldsymbol{B}$. coridifolia and later transfer those cattle to a severely infested area.

\section{MATERIAL AND METHODS}

The study was conducted from July to October in two rural properties whose owners had acquired bovines from areas free of the plant and wanted to test which method would be more efficient to prevent the deaths. Both farms, located in the municipality of Aceguá, (Experiment 1) and in the municipality of Dom Pedrito (Experiment 2 and 3) had historical losses from, and contained substantial populations of mio-mio. We determined the foliar cover of mio-mio by visual observation. All animal procedures for these experiments were approved by the Animal Bioethics Committee of the Federal University of Pelotas.

The experiment one was performed to determinate the efficacy of forced oral administration of $\boldsymbol{B}$. coridifolia with nearly $25 \%$ of the toxic dose to induce aversion. Sixty-one naïve heifers from a farm located in the municipality of Rio Pardo, Rio Grande do Sul, where B. coridifolia does not occur, were introduced to Farm 1. Animals were shipped at 8:00 hours and reached the destination at 14:00 hours on the same day. The cattle remained in a rest paddock of 5ha without mio-mio contamination for about $1 \mathrm{~h}$. Twelve animals were randomly selected and weighed to estimate the average weight of the herd, which was $460 \mathrm{~kg}$. Fifty-one animals were orally dosed with $0.5 \mathrm{~g} \mathrm{~kg} \mathrm{~kg}^{-1}$ body weight of fresh green $\boldsymbol{B}$. coridifolia collected during the growing stage. These animals were divided in three groups and introduced into a paddock where mio-mio covered approximately $15 \%$ to $20 \%$ of the area. The portion of the pasture not covered by mio-mio was predominately grass (Paspalum notatum). To determine the period necessary for the aversion to take effect between the administration of the plant and the introduction of the animals in the area infected by mio-mio, three groups of heifers were introduced at different times in the paddock. Group 1 with 16 heifers was introduced 23-26 hours after the plant was administered, Group 2 with 25 heifers 6-10 hours after administration, and Group 3 with 10 heifers 1-3 hours after administration. Group 4, with 10 naïve heifers, served as controls. Dosing was conducted such that all groups were introduced at the same time into the paddock invaded by mio-mio.

Data were analyzed using the program Statistix 9.0 with a significance level of $\mathrm{P}<0.05$. The frequencies of clinical signs and animal deaths were analyzed by Fisher's exact test.

The experiment two was performed to test if the inhalation of the smoke from burning $\boldsymbol{B}$. coridifolia and rubbing the plant on the animals' muzzles and mouths are effective methods to induce aversion. Twenty adult heifers were transferred to Farm 2 from a farm in the municipality of Santa Vitória do Palmar, Rio Grande do Sul, where B.coridifolia does not occur. They were shipped at 9:10 hours and reached their destination $19 \mathrm{~h}$ later. They were divided 
randomly into two groups with 10 animals each. In the early evening on the day of arrival, heifers from Group 1 were treated following the procedure previously used in the farm. First each animal was treated by rubbing the oral mucosa and muzzle of the heifers with freshly-harvested $\boldsymbol{B}$. coridifolia for 5 minutes. Shortly thereafter, each animal was individually exposed to smoke from burning the partially dry plant (500g per animal) for 1 to 2 minutes. After treatment, all animals were introduced into a paddock recently invaded by mio-mio which covered approximately $1 \%$ of the area. Group 2 remained as a control without undergoing any treatment, and was introduced in the paddock at the same time as Group 1. Four days later, the animals were transferred to another paddock with $\boldsymbol{B}$. coridifolia covering approximately $1 \%$ of the area. Because there were no incidents of poisoning in either the averted or the control group during a 5-month period, the animals were transferred to a paddock with about $20 \%$ cover of mio-mio, to test if the animals became averted during the initial period they spent in the paddock with a low density of mio-mio.

The experiment three was performed to test two forms of aversion simultaneously: the inhalation of the smoke from burning $\boldsymbol{B}$. coridifolia and rubbing the plant on the animals' muzzles and mouths; and the introduction of the animals into an area with a low cover of mio-mio, prior to being introduced into an area severely invaded by the plant. Ten naïve heifers from the municipality of Pelotas, Rio Grande do Sul, were transferred to the same farm used in Experiment 2. All were subjected to oral rubbing and smoke inhalation as previously described, and then introduced into a paddock with good forage availability which had been recently invaded by miomio in approximately $1 \%$ of the area. The animals stayed in that paddock for about 60h, after which they were transferred to another area where mio-mio covered approximately $20 \%$ of the area.

\section{RESULTS}

In the first experiment, twenty-four hours after being released into the area with mio-mio, one heifer from Group 3 (1-3 hours) and three from Group 4 (control) were found dead. Two heifers from Group 4 showed restlessness, bloat, and sternal and lateral recumbence, dying approximately $36 \mathrm{~h}$ after their introduction into the paddock. Two heifers from Group 2 (6-10 hours) showed similar clinical signs, but only one died. Gross findings included dehydration, large amounts of ruminal fluid, and reddening of the mucosa of the forestomachs. Histologically the main change was degeneration and necrosis of the ruminal epithelium. Heifers from Group 1 (23-26 hours) did not show clinical signs of intoxication.

There was a difference in the frequency of deaths between Groups 1 and $4(\mathrm{P}=0.0038)$, and 2 and $4(\mathrm{P}=0.0040)$. There was no difference between Groups 1 and 2 ( $\mathrm{P}=0.609), 2$ and $3(\mathrm{P}=0.495), 1$ and $3(\mathrm{P}=0.384)$, and 3 and $4(\mathrm{P}=0.070)$ by Fisher's exact test. For the frequency of clinical signs there was significant difference between Groups 1 and 4 ( $\mathrm{P}=0.0038)$ and Groups 2 and $4(\mathrm{P}=0.012)$. Therewasno significant difference between Groups 3 and 4 ( $\mathrm{P}=0.07), 1$ and $2(\mathrm{P}=0.366), 1$ and $3(\mathrm{P}=0.385)$, and 2 and $3(\mathrm{P}=0.649)$.

In the second experiment, none of the animals from the treated and control groups showed clinical signs of intoxication or died after being placed into paddocks with only a small area covered with B. coridifolia. Also no clinical signs were observed when both groups were introduced, 5 months later, into a paddock heavily invaded by mio-mio, where they stayed for more than one year.

In the third experiment, none of the 10 animals showed clinical signs of intoxication $60 \mathrm{~h}$ after introduction into an area with nearly $1 \%$ cover of mio-mio. Twenty-four hours after the start of grazing in the area with approximately $20 \%$ cover of mio-mio, 4 heifers showed signs of intoxication. Two of these died about 12 hours after the onset of clinical signs, and the other two died 36 hours later. A fifth animal died approximately 64 hours after entry into the second paddock, but no clinical signs were observed. All dead animals had gross lesions and histological features characteristic of $\boldsymbol{B}$. coridifolia poisoning.

\section{DISCUSSION}

Our results suggest forced administration of $25 \%$ of the lethal dose ( $2 \mathrm{~g} \mathrm{~kg}^{-1}$ of bw) of B.coridifolia as fresh plant material is the best method to reduce cattle death from this plant. However, the time elapsed between the administration of the plant and the poisoning challenge is apparently an important aspect in conditioning an aversion. In Experiment 1 the heifers in Group 1, which were placed in the paddock invaded by mio-mio 23-26 hours after administration of the plant, did not become intoxicated. In contrast, $50 \%$ of the 10 control animals were intoxicated and died. Animals challenged 1-3 hours (Group 3) and 6 hours (Group 2) after treatment were not completely averted, and some of them consumed sufficient plant to cause poisoning and death (Table 1). These results 
Table 1 - Period between administration of $25 \%$ of a lethal dose of $\boldsymbol{B}$. coridifolia to four groups of heifers and the introduction to a paddock invaded by the plant, and number of poisoned and death animals in first experiment.

\begin{tabular}{|c|c|c|c|c|}
\hline Group $^{c}$ & $\begin{array}{l}\text { Period between treatment } \\
\text { and challenge (hours) }\end{array}$ & \# of heifers & $\begin{array}{l}\text { \# of heifers with clinical } \\
\text { signs and relative } \\
\text { frequency }\end{array}$ & $\begin{array}{l}\text { \# of heifers dead and } \\
\text { relative frequency }\end{array}$ \\
\hline 1 & $23-26$ & 16 & $0^{\mathrm{a}}$ & $0^{\mathrm{a}}$ \\
\hline 2 & $6-10$ & 25 & $2(8 \%)^{a}$ & $1(4 \%)^{\mathrm{a}}$ \\
\hline 3 & $1-3$ & 10 & $1(10 \%)^{a, b}$ & $1(10 \%)^{a, b}$ \\
\hline 4 & Control & 10 & $5(50 \%)^{b}$ & $5(50 \%)^{b}$ \\
\hline
\end{tabular}

${ }^{\mathrm{a}, \mathrm{b}}$ Values for Groups followed by different letters are statistically different, $\mathrm{P}<0.05$, using Fisher's exact test.

${ }^{\mathrm{c}}$ Groups 1,2 and 3 were treated with $0.5 \mathrm{~g} \mathrm{~kg}^{-1}$ body weight of fresh green $\boldsymbol{B}$. coridifolia.

suggest that this treatment needs a minimum of 24 hours to induce an aversion to $\boldsymbol{B}$. coridifolia in all animals.

Although one might argue that grazing animals together confounded this test, in fact we view this as a stringent test of the aversion, because all the treated animals were grazing together and without doubt their grazing cohorts eating mio-mio. The strong influence of social facilitation (RALPHS \& PROVENZA, 1999) apparently did not reduce the efficacy of the aversion in Group 1 (23-26h) animals, further evidence of the strength of this procedure.

The toxic compounds in mio-mio macrocyclic trichothecenes, including roridin $\mathrm{A}, \mathrm{D}$, and E, verrucarin A and J, and mycotoxin A (BUSAM et al., 1985) - likely condition an aversion. In cattle and sheep, the first clinical signs of poisoning with B. coridifolia are observed between 3-29 hours after the ingestion of lethal doses of the plant (TOKARNIA \& DÖBEREINER, 1975; TOKARNIA \& DÖBEREINER, 1976; TOKARNIA et al., 2012). This delay between ingestion and signs of intoxication is consistent with our results showing a time lag between ingestion of the plant and induction of an aversion.

The exact mechanism of inducing an aversion is still unclear, however this mechanism probably involves food characteristics (e.g., odor, taste and texture) interacting with toxins that impact the gut and brain (PROVENZA, 1996). A number of central nervous system (CNS) structures are involved in acquisition of taste aversions, including the area postrema, the nucleus of the solitary tract, the parabrachial nucleus (GARCIA et al., 1985), and the central and the basolateral nuclei of the amygdala (YAMAMOTO, 2007). In the absence of CNS activation, other biochemical and physiological lesions will not condition aversions (YAMAMOTO et al., 1998). The CNS and gut receptors are linked so that physiological information on noxious stimuli is transmitted from the gut to the brain. The toxicity of these compounds is poorly understood, but they are thought to inhibit protein synthesis by inhibiting peptide bond formation (MCLAUGHLIN et al., 1977). We speculate that the toxic effect induced by these substances in the gastrointestinal system is responsible for the aversive effect of the plant.

One potential management solution to reduce cattle losses may be to introduce naïve cattle into areas with good forage availability and low cover of mio-mio, as suggested from the results of Experiment 2. However, our results from Experiment 3 indicate that this method is not always reliable, because only $50 \%$ of the animals of the animals survived exposure to a pasture with a higher cover of mio-mio, suggesting that in addition to the ineffective aversive treatment, the animals did not eat enough mio-mio in the first paddock to induce aversion. In contrast, neither experimental group in Experiment 2 got poisoned during the five-month period of grazing in the pasture with a minor presence of miomio, or after being placed in a paddock with large amounts of mio-mio, suggesting that these animals became averted during the five month period that they remained in the low-cover mio-mio pasture. Therefore, placing the animals in areas with good forage availability and small amounts of mio-mio is also an effective way to prevent cattle losses. The minimum period during which the animals must remain in these pastures is unknown, but considering that mio-mio poisoning occurs within one week after the introduction of animals into invaded areas, this period should be at least 7 days. It seems likely that periods of 7 to 30 days of grazing in areas with a low invasion by mio-mio are necessary to avoid later intoxication. 
Another factor influencing the occurrence of mio-mio poisoning in naïve animals is the forage availability of the pastures and the animal's hunger and thirst after transportation (RIET-CORREA \& MÉNDEZ, 2007). Hungry animals should not be placed in areas invaded by mio-mio (BARROS, 1998; TOKARNIA et al., 2012; RIET-CORREA \& MÉNDEZ, 2007). However, in Experiment 3, the animals were introduced first into a paddock with approximately 1\% mio-mio cover and an abundance of good forage. Subsequently half of the cattle died after introduction into an area with $20 \%$ cover of mio-mio. Apparently, these animals were not hungry when they were introduced into the area with the greater challenge, suggesting that forage availability and animal hunger are not decisive factors. Also is evident that the heifers eat any mio-mio in the first, low cover pasture, so they weren't averted and thus died in the high cover pasture. More studies must be performed to determine the correct use of this method, integrating knowledge about the cover of mio-mio, forage availability, and the proper length of time to graze naïve animals under various conditions.

As observed in Experiment 3, burning the plant under an animals' nose and rubbing the plant on the animals' muzzle and mouth were not effective in inducing aversion to $\boldsymbol{B}$. coridifolia in cattle. These techniques were also ineffective in preventing miomio poisoning in sheep (ALMEIDA et al., 2009) suggesting that they should not be used to prevent mio-mio poisoning.

Five days after the beginning of the three experiments, none of the averted and non-averted cattle become poisoned. Individuals from the control groups in Experiments 1 and 2 that survived the challenge also develop an aversion. This is typical behavior seen in non-averted animals introduced into areas with miomio: the animals that do not become intoxicated in the first five days after the introduction in the pastures become permanently averted. Our observations suggest this aversion is never extinguished. Social facilitation appears to have no influence on experienced animals because the aversion is apparently not transient. Social facilitation has been a limiting factor in the usefulness of maintaining aversions to certain toxic plants (RALPHS \& OLSEN, 1992; RALPHS \& PROVENZA, 1999). In the case of mio-mio, it is not known whether the aversion lasts for a lifetime or if the animals remain averted because they are ingesting small amounts of mio-mio mixed with other forage either periodically or continually. Experimentally, the precise length of time that an aversion is maintained to mio-mio has not been determined. Aversions induced by $\mathrm{LiCl}$ to toxic Delphinium can be maintained for up to three years if the animals are kept separate from nonaverted animals (RALPHS \& PROVENZA, 1999).

\section{CONCLUSION}

Based on these results, we conclude that the forced ingestion of controlled (i.e., sub-lethal) doses of $\boldsymbol{B}$. coridifolia by naïve cattle prevents intoxication when animals are placed in areas severely infested by mio-mio after a minimum period of 24 hours postdosing. However, this method may not be viable when a large number of animals need to be moved because of the labor and time involved. In these cases the introduction of animals into paddocks with low infestations (approximately 1\% of the area) would be effective. It is not clear how much time grazing animals should remain in this first pasture before they can be safely moved to pastures containing higher amounts of mio-mio. In these experiments a period of 5 months was effective in preventing poisoning in severely infected pastures, but it seems likely that a smaller initial residence time (e.g., 7 to 30 days) in the low abundance pasture may be sufficient to condition an aversion and greatly reduce livestock losses.

\section{ACKNOWLEDGMENTS}

This work was funded by Conselho Nacional de Desenvolvimento Científico e Tecnológico (CNPq) (Proc. n.471588/2004-0) and by the National Institute of Science for the Control of Plant Poisoning, grant no.573534/2008-0. We thank Dr. Leo Lucas, DVM, for providing animals and experimental areas in Dom Pedrito/RS, Brazil.

\section{REFERENCES}

ALDA, J.L. et al. Intoxicação espontânea por Baccharis coridifolia (mio-mio) em eqüinos no Rio Grande do Sul. Pesquisa Veterinária Brasileira, v.29, p.409-414, 2009. Available from: $<$ http://www.scielo.br/scielo.php?script=sci_serial\&pid=010036X\&lng=en\&nrm=iso>. Acessed: March 2010 doi: S0100736X2009000500009.

ALMEIDA, M.B. et al. Conditioned aversion in sheep induced by Baccharis coridifolia to a previously unknown food. Applied Animal Behaviour Science, v.117, p.197-200, 2009. Available from <http://www.journals.elsevier.com/appliedanimal-behaviour-science>. Accessed: May. 10, 2010 . doi: S0168159108003389.

BARROS, C.S.L. Livestock poisoning by Baccharis coridifolia. In: GARLAND, T.; BARR, A.C. (Ed). Toxic plants and other natural toxicants. England: Wallingford, 1998. p.569-572.

BUSAM, L. et al. Macrocytic trichothecenes: causes of livestock poisoning by the Brazilian plant Bacharis coridifolia. Toxicon, v.23, p.731-745, 1985. Available from: <http://www.sciencedirect. 
com/science/article/pii/0041010 185900030>. Accessed: May. 20, 2010. doi: 0041010185900030 .

COBO, B. Historia del nuevo mundo. Madrid: Biblioteca de Autores Españoles, [re-edited in 1964]. V.92, 1653. p.226-227

GARCIA, J. et al. A general theory of aversion learning. Annals of the New York Academy of Science, v.443, p.8-21, 1985. Available from: <http://onlinelibrary.wiley.com /doi/10.1111/ nyas.1985.443.issue-1/issuetoc>. Accessed: May. 30, 2010. doi: 10.1111/j.1749-6632.1985.tb27060.x.

MCLAUGHLIN, C.S. et. al. Inhibition of protein synthesis by trichothecenes. In: RODRICKS, J.V. et al. Mycotoxins in human and animal health. Illinois: Pathotox Publishers, 1977. p.263273.

PROVENZA, F.D. Acquired aversions as the basis for varied diets of ruminants foraging on rangelands. Journal of Animal Science, v.74, p.2010-2020, 1996. Available from: <http:// www.journalofanimalscience.org/content/74/8/2010.full.pdf $>$. Accessed: May. 28, 2010. doi: 74/8/2010.

RALPHS, M.H.; OLSEN, J.D. Comparison of larkspur alkaloid extract and lithium chloride in maintaining cattle aversion to larkspur in the field. Journal of Animal Science, v.70, p.11161120, 1992. Available from: <http://journalofanimalscience.org/ content/70/4/ 1116.full. pdf+html>. Accessed: May. 23, 2010. doi: $70 / 4 / 1116$.

RALPHS, M.H.; PROVENZA, F.D. Conditioned food aversions: principles and practices, with special reference to social facilitation. Proceedings of Nutrition Society, v.58, p.813-820,1999.Available from:<http://journals.cambridge.org/download.php?file $=\% 2$ F21613A3F60DCF5F2828EEE8B8613C143AD42_journalsPNS PNS58_04_S002966519900110Xa.pdf\&cover $=$ Y \&code $=598 \mathrm{ab}$ 0a6f07230fd0e528452fc6608c7>. Accessed: Jun. 01, 2010. doi: 598ab0a6f07230fd0e528452fc6608c7.
RIET-CORREA, F.; MÉNDEZ, M.C. Intoxicações por plantas e micotoxinas. In: RIET-CORREA, F. et al. Doenças de ruminantes e eqüídeos. Rio Grande do Sul: Editora Pallotti. 2007. p. 99-221.

RISSI, D.R. et al. Intoxicação espontânea por Baccharis coridifolia em bovinos. Pesquisa Veterinária Brasileira, v.25, p.111-114, 2005. Available from: <http://www.scielo.br/scielo. php?script=sci_serial\&pid=0100-736X\&lng $=$ en\&nrm $=$ iso $>$. Accessed: May. 10, 2010. doi: S0100-736X2005000200008.

ROZZA, D.B. et al. Intoxicação espontânea por Baccharis coridifolia (Compositae) em ovinos. Pesquisa Veterinária Brasileira, v.26, p.21-25, 2006. Available from: <http:// www.scielo.br/scielo.php?script $=$ sci_serial\&pid $=0100$ 736X\&lng=en\&nrm=iso>. Accessed: May. 9, 2010. doi: S0100736X2006000100005.

TOKARNIA, C.H., DOBEREINER, J. Intoxicação experimental em bovinos por "mio-mio", Baccharis coridifolia. Pesquisa Agropecuária Brasileira, v.10, p.79-97, 1975.

TOKARNIA, C.H.; DÖBEREINER, J. Intoxicação experimental em ovinos por "mio-mio", Baccharis coridifolia. Pesquisa Agropecuária Brasileira, v.11, p.19-26, 1976.

TOKARNIA, C.H. et al. Plantas Tóxicas do Brasil para animais de produção. Rio de Janeiro: Helianthus, 2012. 566p.

YAMAMOTO, T. et al. The roles of chemical mediators in the taste system. Japanese Journal Pharmacology, v.76, p.325348, 1998. Available from: <https://www.jstage.jst.go.jp/ article/jjp/76/4/76_4_325/_pdf>. Accessed: Jun. 12, 2010. doi: 76/4/76_4_325.

YAMAMOTO T. Brain regions for the expression of conditioned taste aversion in rats. Chemical Senses, v.32, p.105-109, 2007. Available from: <http://chemse.oxfordjournals.org/ content/32/1/105.full>. Accessed: Jun. 12, 2010. doi: 32/1/105. 